\title{
Robotos szerelési kísérletek háromujjas megfogóval
}

\author{
Paniti Imre ${ }^{1,2}$, Nacsa János ${ }^{1,2}$, Abai Kristóf $f^{1,2}$ \\ 1: Termelésinformatikai és Termelésirányitási Kiválósági Központ (EPIC), \\ Számitástechnikai és Automatizálási Kutatóintézet (SZTAKI), \\ 2: Jármüipari Kutatóközpont (JKK), Széchenyi István Egyetem (SZE) \\ paniti.imre@sztaki.hu, nacsa.janos@sztaki.hu, abai.kristof@sztaki.hu
}

\section{Robotic assembly experiments with three-finger gripper}

The article introduces a collaborative workspace built around the Industry 4.0 Sample System with a Collaborative Robot (a so called Cobot) using a 3-finger gripper. It describes in detail the developments that allow independent movement of the 3 fingers. It shows what kind of force sensors are used in the system and the capabilities of them. The Virtual Reality (VR) model of the system is also presented, where the model follows the movements of the system in real-time by continuously reading the Kinect sensor (RGB camera and depth sensor) input and the joint coordinates of the robot. Finally, three demonstration applications are described.

Keywords: Robotised assembly, Industry 4.0, VR modelling

\section{Bevezetés}

Az ipar folyamatos fejlödésének köszönhetően az elterjedt és széles körben alkalmazott technológiák kereteit lassan kinőtték az egyre növekvő és szerteágazó igények. Ezek a változások olyan jelentősek, hogy új ipari korszaknak tekinthető ezek bevezetése, így joggal mondhatjuk, hogy napjainkban is zajlik a negyedik ipari forradalom, vagy ismertebb szóhasználattal élve, az Ipar 4.0 korát éljük. Ez az átalakulás jól szemléltethető az 1 . ábrán látható virtuális és fizikai világ konvergenciájával.

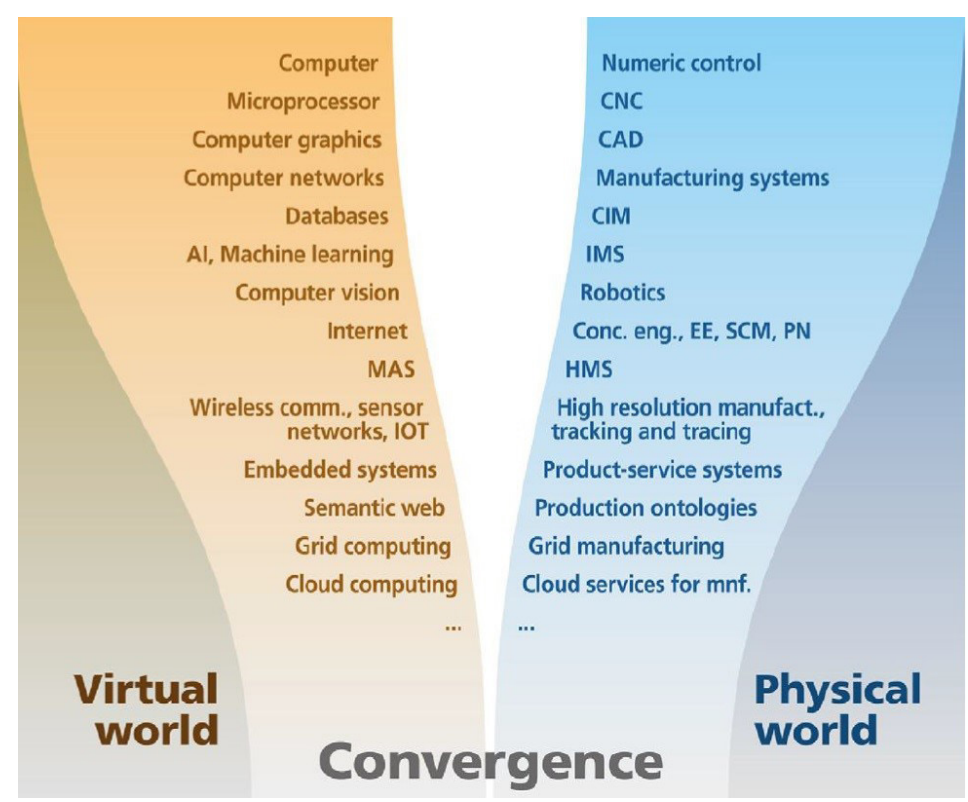

1. ábra: A virtuális és fizikai világ konvergenciája [1] 
Mivel rengeteg kérdés merül fel az új technológiákkal kapcsolatban, és számos még megoldásra váró feladat áll elöttünk, szükségét láttuk egy olyan laboratórium létrehozásának, melyben megépithető egy olyan kis ipari környezet, egy mintarendszer, melyben lehetőség van az újitások kipróbálására, tesztelésére, összetettebb rendszerek tervezésére és implementálására, illetve lehetöség van új felmerülő problémák megoldására és a megoldások bemutatására is. Ezen felül a rendszer az oktatásban is jelentős szerepet vállalhat, lehetőséget nyújt arra, hogy a hallgatók, már az egyetemi tanulmányaik alatt megismerhessék a fejlődési irányokat, találkozzanak az új technológiákkal.

A 4. Ipari forradalom magába foglalja a robotok fejlődését is, igy a hagyományos ipari robotok mellett megjelentek a könnyüsúlyú kollaborativ (együttmüködö) robotok, amelyek mozgásától már nem kell megvédeni az embereket különböző ipari biztonságtechnikai eszközökkel, mivel felépítésükböl és vezérlésükből adódóan nem árthatnak különösebben az azokkal kapcsolatba kerülöknek.

A Fraunhofer Institute for Industrial Engineering (FhG IAO) készitett egy tanulmányt [2], melyben arra mutat rá, hogy az ember-robot együttmüködés hatékonyan alkalmazható, az automatizált és tisztán humán munkaerőt foglalkoztató termelésben is. A tanulmány célja továbbá az volt, hogy megmutassa a kis- és középvállalatoknak, hogy a könnyüsúlyú robotok alkalmazása számukra is megtérülö beruházás lehet, növelheti a termelékenységet még abban az esetben is, ha kis sorozatnagyságokat gyártanak nagyszámú termékváltozat mellett. Az eddigi nagy beruházást igénylő automatizálás most a relatív olcsó könnyűsúlyú robotoknak köszönhetöen nemcsak a nagyvállalatok privilégiuma.

A felmérésben feltárták, hogy a cégek miért választották az adott alkalmazás tervezésekor, a könnyüsúlyú robotok alkalmazását, azember-robot együttmüködést (2. ábra). A megkérdezett vállalatok $80 \%$-a számított arra, hogy ezzel a beruházással hatékonyabb lesz a termelés. Sok cég innovációs céllal fogott bele a kollaborativ munkavégzésbe, és a cégek több mint felénélszempont volt az ergonómia növelése, ezzel a dolgozók munkájának kényelmesebbé és biztonságosabbá tétele. Ezen kivül még sok más indokot felsoroltak a gyártók, mint például az összeszerelési idő csökkentése, monotonitás csökkentése, rugalmasság növelése.

A 3. ábrán látható, hogy a felmérésben szereplő alkalmazásokban milyen típusú múvelet végrehajtására alkalmazták a robotokat. 


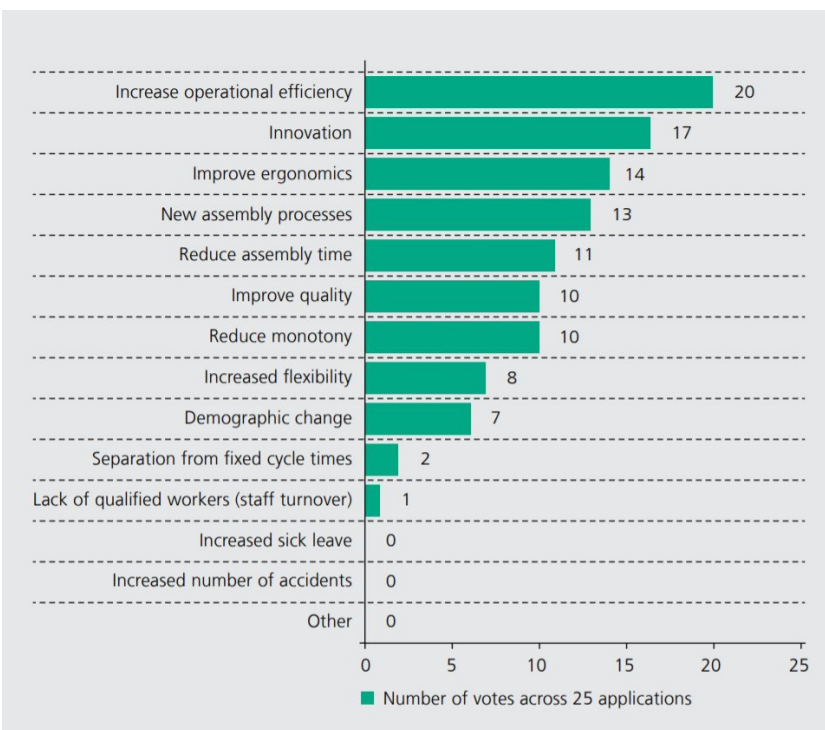

2. ábra: könnyüsúlyú robotok alkalmazásának okai [2]

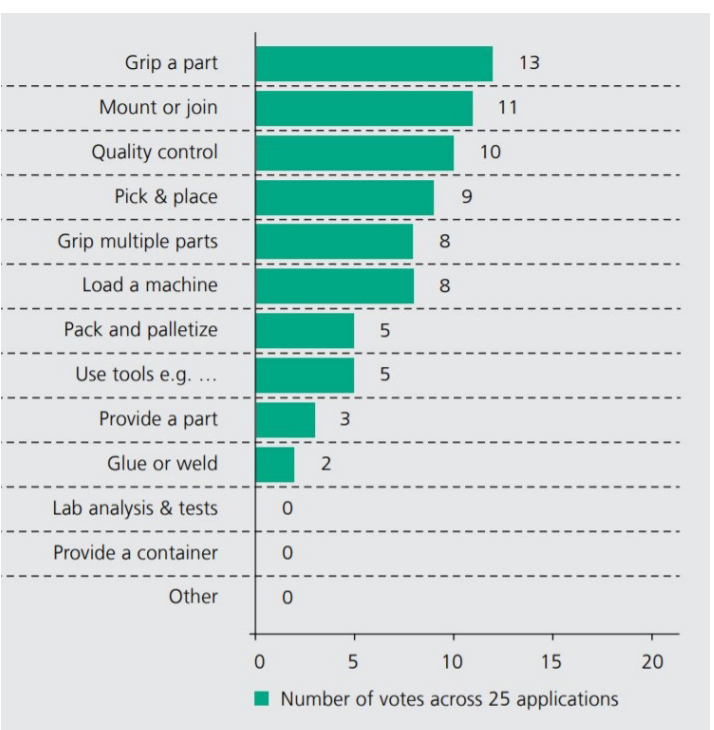

3. ábra: felmérésben szereplő robotok alkalmazásának típusai [2]

A felmérésből látszik, hogy a robotok nagy százalékban valamilyen megfogó segitségével alkatrész manipulációt végeznek. Ehhez általában vákuumos megfogót, vagy kétujjas megfogót alkalmaznak.

\section{Kobotos szerelésben alkalmazott kétujjas megfogók és korlátaik}

Az iparban használatos kétujjas megfogóknak a költsége sok esetben egy nagyságrendbe eshet a robot költségével, továbbá ahhoz, hogy a megfogó egy adott termék megfogására alkalmas legyen megfogópofa tervezése és gyártása is szükséges, amely sok esetben nem egyszerü, gyakran költséges feladat és a termék esetleges változása, vagy egy másik termékre való átállás másik megfogópofa alkalmazását igényli. Ennek ára bizonyos esetekben minimálisra csökkenthetö, amennyiben a megfogópofa 3D nyomtatás segitségével elöállitható. Előfordulhat, hogy egyes alkalmazásoknál komplexebb megfogást kell alkalmazni, ami már a két ujjas megfogóval nem kivitelezhető. Ezekben az esetekben jöhetnek szóba a háromujjas megfogók.

\section{Háromujjas megfogó alkalmazási módjai és vezérlésének továbbfejlesztése}

A 4. ábra bal oldalán a "pinch" módban a megfogó 2 ujjasként müködik, mivel az egyező oldalon levő "B" és "C" ujja összezárva együtt mozog. A következő mód az "scissor", amikor pont ezt az összezáró-szétnyiló képességet használjuk egy tárgy felcsippentésére. A harmadik "wide" módban a "B" és "C" ujjak legyezőszerüen szétnyilva széles megfogást biztositanak hosszabb tárgyak biztos megfogására. A bal szélső "normal" megfogás esetén a három ujj az összezáródás síkjában párhuzamosan mozog és a tárgy relatív helyzetétöl függően rá is fordulnak az ujjpercek a tárgyra. 

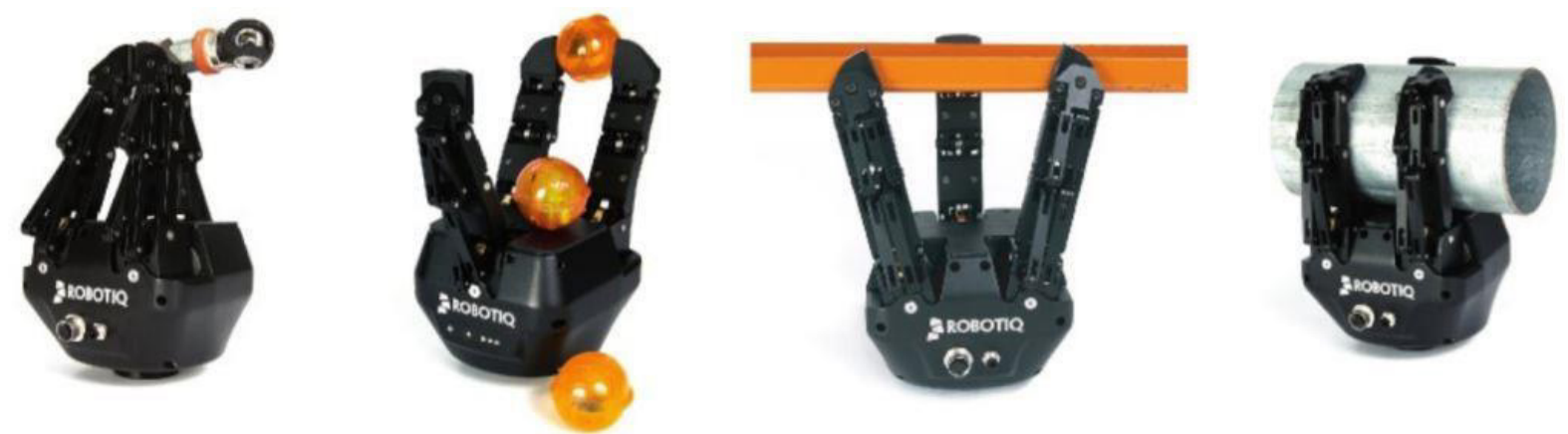

4. ábra: A Robotiq háromujjas megfogójának fogástípusai

Ilyen típusú megfogót alkalmazott négy csapat (köztük a gyöztes is) a DARPA 2013as robotikai versenyén [3].

A LinkageDesigner [4] a Wolfram Mathematica egy add-in csomagja, amely mechanizmusok tervezésre, modellezésre, valamint szimulációra alkalmazható. 2006-óta a Wolfram Research terméklistáján is szerepel. Ennek a programcsomagnak a használatával képesek vagyunk egész ipari cellák modelljeinek előállítására, segítségével létrehozhatjuk a cella digitális ikerpárját. Ahhoz, hogy el tudjuk készíteni a megfogó „Linkage" modelljét, pontos geometriai modellre volt szükség. Mivel a gyártó csak befoglaló geometriát ad közre, így "Reverse engineering" módszerrel elkészitettük a megfogó pontos geometriai modelljét (5. ábra), igy a Linkage skeleton modellje már pontos geometriai paraméterekkel is feltölthettük.

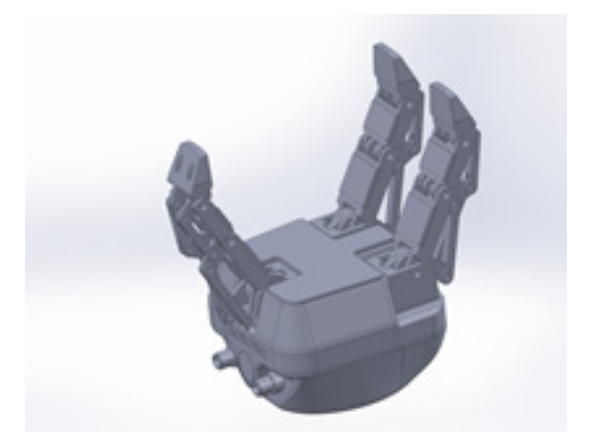

5. ábra: A háromujjas megfogó 3D modellje

Az így kapott megfogó modell integrálható egy robotos cella modelljébe, mely mint digitális ikerként pl. az ApertusVR segitségével megjelenithető.

Az ApertusVR [5] egy MIT licenszü, nyiltt forráskódú, platformfüggetlen programozói könyvtár, amit az SZTAKI megosztott virtuális valóság csoportja fejleszt, többek között azzal a céllal, hogy az iparban alkalmazott merev, vizualizációs célokra használt szoftvereket kiváltsa. Külső szenzorok jeleinek beágyazása és megjelenitése sokkal egyszerübb ezzel a rendszerrel, mint a hagyományos, többnyire 3D-játékok fejlesztésére használt programokkal. Virtuális, kiterjesztett és kevert valóság integrálására egyaránt használható, így a robotos környezetünkben is kiválóan tudjuk alkalmazni a mélységi kamerából nyert adatok és a 3D modell "összefésülésénél". Skálázhatósága és elosztottsága révén könnyen illeszthető már 
meglévő alkalmazásokhoz (mint például az IBM Node-RED [6] nevü programjához), egy új alapvetően vizuális absztrakciós réteget képezve a hardverek és a szoftverek között.

Az elöbb emlitett Node-RED-et kifejezetten loT alkalmazások gyors prototipusfejlesztéséhez találták ki, ahol különböző típusú rendszereket kell összekapcsolni.

Mi az ApertusVR könyvtárat kapcsoltuk össze a magas szintü robotvezérlésünkkel (az URSZTAKI-val), amiben a 3 ujjas megfogó is helyet kapott. Az URSZTAKI keretrendszer létrehozásának több célja is volt.

Egyrészt egy olyan felület létrehozása, ami lehetővé teszi a robotok moduláris programozását, hogy a robot-programnyelv-függetlenités mellett a késöbbiekben magasabb szintü vezérlöhöz (pl. MES-hez) lehessen csatlakoztatni a rendszert.

Másrészt olyan keretrendszer kidolgozása, amelyben könnyen lehet létrehozni új alprogramokat (feladatokat) és ezeket egyszerüen el lehet juttatni további robotokra.

Harmadrészt olyan modularitás kidolgozása, amellyel könnyedén kezelhetőek a különböző felszereltségü robotok.

Ezen célok elérése érdekében a program script fájlokra épül, amelyek beágyazódnak a robotprogramba, majd onnan néhány függvény hivásával indulnak. Ezáltal a módosításokhoz csak szöveges fájlokat kell átírni, azok frissitése könnyen automatizálható és verziójuk követhetö. A megvalósitás esetünkben UR robotkarokkal történt.

A Robotiq 3 ujjas megfogója kifejezetten támogatja UR kobotokra való felszerelését, mind hardveresen, mind a kobot script nyelvébe ágyazódó speciális utasitáskészlettel. A részletes dokumentáció azonban megmutatta, hogy az UR script szoftver nem használja ki a megfogó összes képességét (4. ábra), csak egy limitált elemkészlet került implementálásra. Ebböl az okból kifolyólag saját fejlesztéssel a scriptet bővitettük, mely már lehetővé teszi az egyes ujjak független mozgatást mind a négy mozgási irányba ("A", "B" és "C" ujjak valamint a "B" és "C" ujj egymás felé való "S" mozgását). A saját fejlesztésü script mozgásonként megadja a müvelet után a fenti négy pontos pozíciót, valamint azt, hogy egy megfogási müvelet során melyik ujj érte el a programozott értéket, vagy tárgyat érzékelve korábban állt-e meg. Ezzel a bővített scripttel fut az URSZTAKI.

A csukló-koordinátáinak a robotvezérlö egységétöl TCP/IP protokollt és egy belső hálózatot használva jutnak el a 3D-s megjelenitöhöz, ami szinte valós időben tudja követni a robot mozgását, egyfajta digitális ikert, vagy más néven árnyékot képezve (6. ábra). 


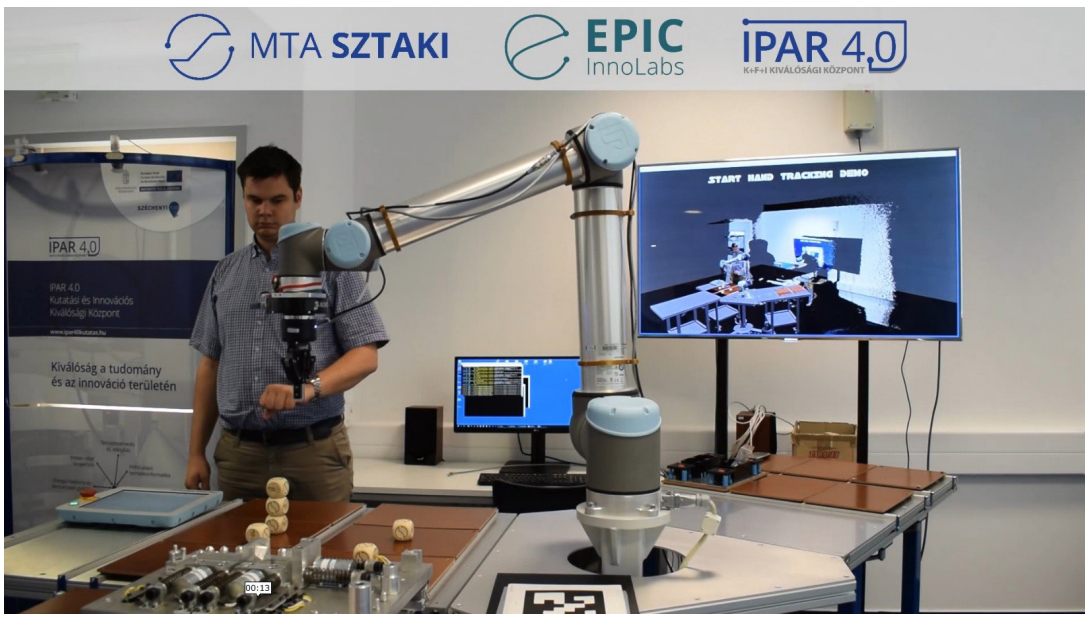

6. ábra: UR10-es kobotos környezet és a digitális iker megjelenitése a háttérben

\section{Példák bemutatása}

Ebben a részben három példán keresztül szeretnénk bemutatni az eddigi fejlesztéseinket.

\section{1. példa: 3D szkennelés robottal - 7. ábra}

A kollaboratív munkakörnyezethez véleményünk szerint hozzátartozik, hogy az emberekés a kobotok osztozzanak a munkaeszközökön is. Ez csakakkor lehetséges, ha mindkét fél meg tudja fogni a tárgyalt eszközt. Az embereknek szánt termékek esetében az ergonómia már alap terméktervezési követelmény, de amennyiben azt szeretnénk, hogy a kobot is meg tudja fogni ugyan azt az eszközt, akkor gyártásnál erre is figyelni kell, vagy ki kell egészitenünk egy adapterrel a terméket, aminek a csatlakozását biztositani kell. Esetünkben az utóbbit választottuk, hogy egy állványra is rögzithető kézi szkennert a kobot mozgatni tudjon. Az optimális szkennelés céljából a TCP (Tool Center Point) értékét (ami a robot „munkapontja”, egy relatív pozíció az utolsó csukló végéhez viszonyitva) a szkennelési távolságnak megfelelően kellett beállítani, amit azáltalunk használt Artec Space Spider technikai specifikációja [7] határozott meg.

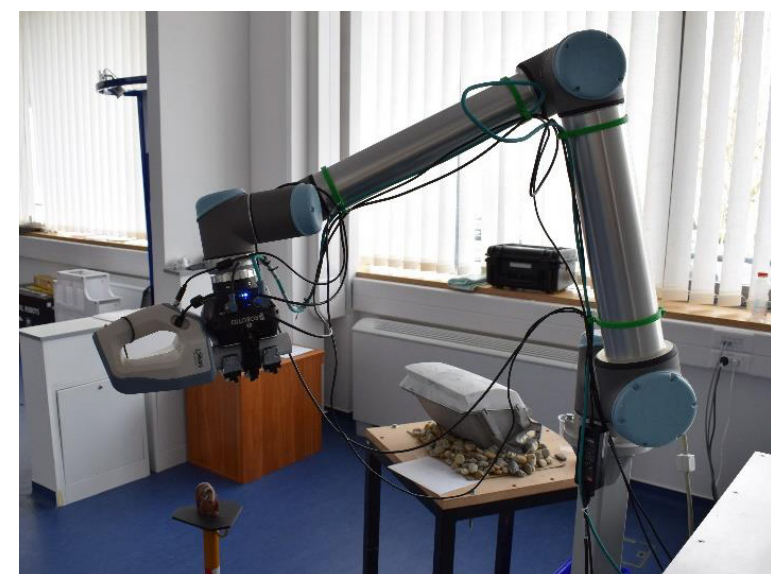

7. ábra: UR10-es kobotos szkennelés

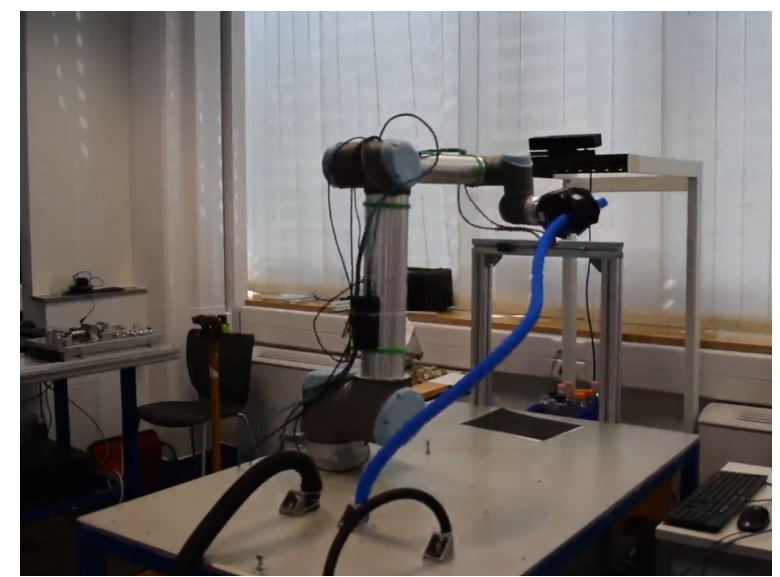

8. ábra: Rugalmas cső manipuláció UR10-es kobottal 
2. példa: Rugalmas csövek csatlakoztatása - 8. ábra

Az iparban egy nem szokványos és kihivásokkal teli feladat a rugalmas csövek manipulációja, ami egy háromujjas megfogóval stabilabb megvalósítást eredményezhet. Esetünkben nem csak a megfogó normál megfogását alkalmaztuk, de a megfogási detektálást is. A robot megfelelő mozgáspályájának programozása történhet kizárólag az egyik rögzitett csövég, a csőhossz és a csatlakozási pozíció ismeretében, vagy a késöbb akár az ArtiMinds RPS [8] és egy erő-nyomatékmérö cella segitségével.

\section{Példa: Müanyag palack felemelése - g(c) ábra}

Robotos környezetben sok olyan feladat létezik, ahol valamilyen kis mechanikai teherbírással rendelkezö, törékeny vagy könnyen deformálható tárgyat kell manipulálni a robot segitségével. Már tárgyaltuk, hogy milyen sok megfogási módot alkalmazhatunk, azonban egyiknél sem tudunk valós idejü és pontos visszajelzést kapni a megfogott teströl.

Ahhoz, hogy a megfogónkat minél összetettebb és egy egyszerü megfogó képességeit meghaladó feladatok megoldására is képessé tegyük, az ujjak utolsó tagjára (az ún. "Distal Phalanx” részre) egy-egy erőmérő szenzort - 9(a) ábra rögzitettünk 3D nyomtatott adapter - 9(b) ábra - segítségével [9], így pontosan mérhetjük, hogy a megfogási pontokban mekkora eröhatás éri a megfogott tárgyat. A kisérletek várakozásunkkal ellentétben azt mutatták, hogy a pontos erőhatás mérése mellett nem becsülhetö jól a felemelt tárgy tömege, mert az ismétléses mérések nagy szórást mutattak.

Ugyanakkor sikeres volt a feladat abból a szempontból, hogy ezzel a rendszerrel képesek vagyunk felemelni egy üres PET palackot, annak megroppantása nélkül, amit abban az esetben is megtart a robot, ha azt emelés közben megtöltjük vízzel.

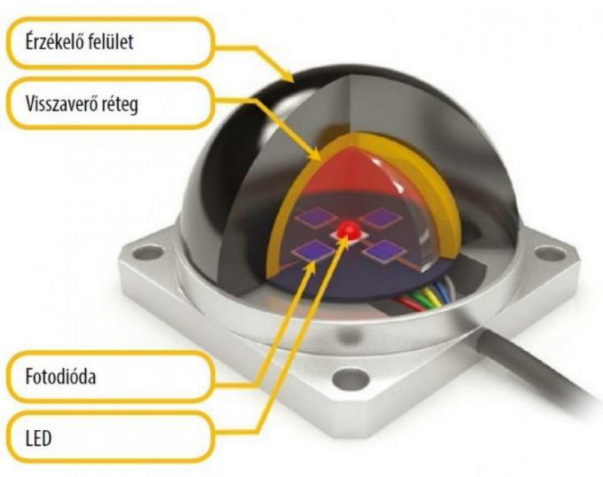

(a) [10]

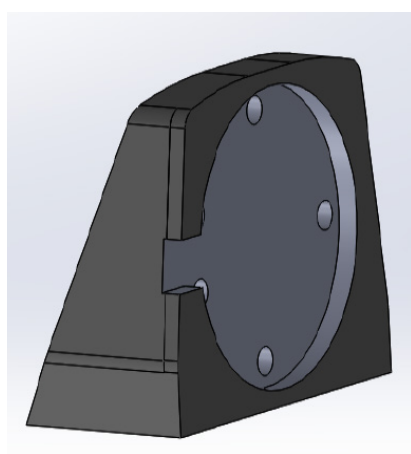

(b)

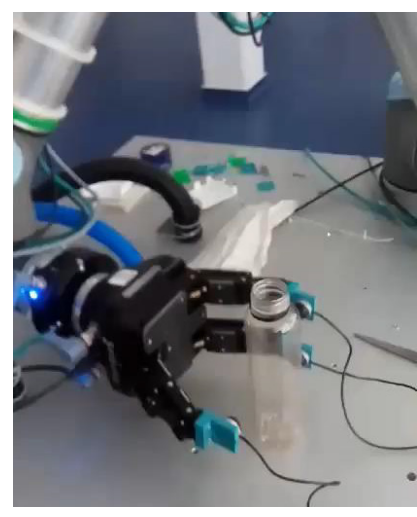

(c)

9. ábra: Erömérő szenzorokkal kiegészitett megfogó alkalmazása

Hasonló kísérleteket végzett KABOLI kollégáival együtt [11]. 


\section{Összegzés}

Az ismertetett környezet alkalmas arra, hogy gyorsan újabb példaalkalmazásokat fejlesszünk, az Ipar 4.0 elveinek megfelelően az alkalmazások digitális ikerpárját is létrehozva, valamint egyedi feladatokra is egységesitett környezetben dolgozhassunk.A három példa mutatjaa 3ujjas megfogósokrétükihasználhatóságát. Ugyanakkor a tapasztalatunk azt mutatja, hogy a megfogó sokféle üzemmódjának elönyeit jelentősen korlátozza a megfogó relativ nagysága a robotkarhoz viszonyitva. Sok alkalmazás, amely felmerült, a megfogó mérete és kábeligénye miatt (3 csatlakozása van) nem valósitható meg. Az ujjakra szerelt erőszenzorok helyett a közeljövöben a kar és a megfogó közé illesztett hagyományos 6 tengelyes eröszenzorral kivánjuk a kisérleteket folytatni.

\section{Köszönetnyilvánitás}

A bemutatott kutatást a „Felsőoktatási Intézményi Kiválósági Program - Digitális ipari technológiák kutatása a Széchenyi István Egyetemen" projekt (20523-3/2018/ FEKUTSTRAT) támogatta. A kutatáshoz szükséges infrastruktúra pedig az „Ipar 4.0 kutatási és innovációs kiválósági központ" projekt (GINOP-2.3.2-15-2016-00002) keretében valósult meg.

\section{Irodalomjegyzék}

[1] Monostori, L., Kádár, B., Bauernhansl, T., Kondoh, S., Kumara, S., Reinhart, G., Sauer, O., Schuh, G., Sihn, W. and Ueda, K., 2016. Cyber-physical systems in manufacturing. Cirp Annals, 65(2), pp.621-641.

[2] Bauer, W., Bender, M., Braun, M., Rally, P. and Scholtz, O., 2016. Lightweight robots in manual assembly - best to start simply. Frauenhofer-Institut für Arbeitswirtschaft und Organisation IAO, Stuttgart.

https://www.produktionsmanagement.iao.fraunhofer.de/content/dam/ produktionsmanagement/de/documents/LBR/Studie-LeichtbauroboterFraunhofer-IAO-2016-EN.pdf, utolsó letöltés: 2019.10.16.

[3] https://blog.robotiq.com/bid/69213/DARPA-Robotic-Challenge-2013-WonUsing-Robotiq-Adaptive-Grippers, utolsó letöltés: 2019.10.16.

[4] www.linkagedesigner.com/, utolsó letöltés: 2019.10.16.

[5] http://apertusvr.org/, utolsó letöltés: 2019.10.16.

[6] https://nodered.org/, utolsó letöltés: 2019.10.16.

[7] https://www.artec3d.com/portable-3d-scanners/artec-spider\#specifications, utolsó letöltés: 2019.10.16.

[8] https://www.artiminds.com/, utolsó letöltés: 2019.10.16.

[9] Bencze Kristóf: Eröszenzor alkalmazása robotos környezetben, Diplomaterv, BME GTT, 2018

[10] http://www.techmonitor.hu/piacmonitor/elemezes-velemeny/az-ero-legyenveled-20161001, utolsó letöltés: 2019.10.16.

[11] Kaboli, M., Yao, K. and Cheng, G., 2016, November. Tactile-based manipulation of deformable objects with dynamic center of mass. In 2016 IEEE-RAS 16th International Conference on Humanoid Robots (Humanoids), IEEE, pp. 752-757. 